\title{
Critical thinking; the father of all disciplines
}

\author{
Akapo M. Adeyinka \\ Department of Philosophy, University of Abuja, Abuja, Nigeria. \\ Email: addayinka@gmail.com; Tel: +2348056554644.
}

Copyright (@) 2021 Akapo. This article remains permanently open access under the terms of the Creative Commons Attribution License 4.0, which permits unrestricted use, distribution, and reproduction in any medium, provided the original work is properly cited.

Received 4th November, 2021; Accepted 6th December, 2021

\begin{abstract}
Looking at the history of philosophy, one will see that philosophy is often credited with the attributes of critical thinking, hence, critical thinking is always discussed as a tool of or the same as philosophy. Whereas it seems almost impossible to find philosophy or philosophizing without critical thinking, it may not be true to say that they are the same. This work therefore, demonstrates that philosophy and critical thinking are very complementary, but are not same, and critical thinking is not a tool of philosophy. It agrees that philosophy is the mother, but show that critical thinking is the father, of rational enquiries. For long, critical thinking and philosophy have served to produce results of rational enquiry hence the identification of the critical thinking DNA as is found in all the results of rational and creative thought. Adopting the method of critical analysis, this work concludes that critical thinking should be seen and appreciated for what it is and that it is better for all disciplines to emphasize the need and role of their paternal (critical thinking) DNA as it is what brings them to their pragmatic utilitarian value.
\end{abstract}

Keywords: Complementary, curiosity, DNA, feminists, interdisciplinarity, skepticism.

\section{INTRODUCTION}

Philosophy did not start as curiosity; philosophy began with curiosity. A desire to learn and to know more about something, anything. This desire, once hits man, engulfs his mind to want to do something about it. It is like being intellectually horny (it is not a human act, but is an act of man). It can also be likened to an animal's being in a heat period desirous of fertilization out of the readiness for reproduction. But of course, desire cannot fertilize itself. Just as curiosity cannot yield much on its own, hence the role of critical thinking (which is a human act). Observe that Merriam Webster's dictionary and Thesaurus (2021) accounts for curiosity as an "interest leading to inquiry". As such, it is safe to say that while philosophy is and stops at curiosity, critical thinking comes in, in the form of skepticism and questioning for the purpose of clarity, identification, understanding and demystification.

While acts of man are acts that do not involve conscious choice through the involvement of reason and will. They are acts that are involuntary and void of personal control. Human acts, are those acts that are done out of conscious deliberation. They are acts that according to Thomas Aquinas are the subject of human morality as they involve the use of the intellect and will (Ajanwachukwu, 2015; p.62). The difference between human acts and acts of man can be said to be that human act happen, acts of man are made to happen.

In the early Greek thoughts, having seen the world as it is, and being dissatisfied with religious explanations, the early Greek thinkers felt that there ought to be more to reality and existence than the apparent. And this struck their curiosity. They were curious about what things were, why they were the way they were, how they came to be, but could not make anything out of it until they started to engage in critical thinking by asking the fundamental questions that brought the need for clarity and understanding. Questions like; "why something instead of nothing?" This was the point where philosophy itself ended its emotional relationship with religion and got married to critical thinking. This was the point where philosophy began to utilize its potentials. Philosophy became the love of wisdom. Wisdom being critical thinking. No wonder Socrates was said to be a midwife with a teaching method described by Taylor (2012) as cited in Changwong et al. (2018) as "critical questioning" in order to put to birth the 
content of the minds of his audience. Audiences who developed philosophy and were fertilized through critical thinking to birth new ideas. Ideas that were shaped through further critical thought and inquiry. Changwong et al. (2018; p. 40) identified two goals behind the Socratic method as; "to show them that they did not know what they thought they did and to push them into critically examining their ideas for themselves".

As such, it shall be demonstrated that there is the critical thinking DNA in all rational inquiries and that critical thinking is the father of rational inquiries just as philosophy is said to be the mother of all rational inquiries. This shows the need for the intellectual foundations of actions and disciplines to be understood and emphasized in relation to critical thinking so as to enable us achieve the best utilitarian values from rational inquiries.

\section{WHAT IS CRITICAL THINKING?}

What it means to be critical is commonly misused and or misunderstood. For this reason, it is imperative to briefly examine the term "critical." It may also suffice to briefly show what being critical is not. It is not being negative. It is not being deliberately antagonistic for antagonism sake. Yes, sometimes, the need to be critical may lead you to oppose or resist certain people, things or views, but it is never to be for that end alone, but towards a greater good or the avoidance of certain ills. Being critical is not being pessimistic, even as the process is sometimes mistaken to be.

Being critical is a careful process of evaluation to spot loopholes, dangers, or mistakes and their possibilities. It involves a careful evaluation of judgements. It also involves making critiques. Critiques being identification and examination of weaknesses and strengths in arguments (Changwong et al., 2018; p. 41). What then is critical thinking?

In the views of Moore and Parker (2009; p.3), critical thinking is the careful application of reason to determine whether a claim is true. Stating this, they called our attention to notice that it is not so much of coming up with true or false claims, that constitutes critical thinking. Rather, it is the evaluation of claims, however we come up with them. You might say that our subject is really thinking about thinking -we engage in it when we consider whether our ideas really make good sense. Of course, since our actions usually depend on what thoughts or views we have accepted, whether we do the intelligent thing or not, also depends on how well we consider those thoughts and views (Moore and Parker, 2009; p.3). As noted by Salmon (2007; p.3), aspects of critical thinking involve: (1) gathering evidences and (2) determining whether they support or undermine assertions.

Also, and very importantly, it involves paying careful attention to information that we take in, so that we can understand them and respond appropriately. Knowing when to seek evidences requires sensitivity to the contexts and circumstances in which words are spoken or written. A critical thinker should understand the differences between evidences and other devices that are used to make us believe what is said. Take for instance, adverts that show how families can be happy because they consume certain products. And adverts that use models to show how strong a person can be from the use or consumption of certain products. The families or models in such adverts are not evidences and should not be mistaken as one, for the effectiveness of such product. They often come as appeals to people's deepest cravings and can best be tackled by the avoidance of fallacies. Fallacies, simply being, instances of poor or faulty reasoning and inferences (Baggini and Fosl, 2010; p.23).

As such, Diestler and Mahy (1998; p.2) were correct to hold the view that a critical thinker is someone who uses specific criteria to evaluate reasoning, form positions, and make decisions. Such criteria as was presented by Salmon (2007; p. 4) who observed that critical thinking also involves other abilities, such as thinking coherently, comprehending instructions and advice, formulating problems and solving them, judging whether bits of information are relevant to an issue, surveying possible outcomes of decisions and plans, and deciding how to make the best choices from those available. Also, in attempt to synthesize the qualities of a strong critical thinker, Foresman et al. (2016; p.5) wrote that;
a strong critical thinker, in sum, should be able, not only to wield the tools of logic and science but also those that illuminate the complexities of language and communication, as well as those that help confront, advance, or resist the principal forms of morality and politics at work in the world today.

Critical thinking for them, should not only be directed towards improved inquiry into questions of truth and falsehood but also into issues of meaning more generally as well as imperatives and possibilities of moral and political action. The implication of this is that, critical thinking should not just be theoretical but practical as well. It should guide us towards the knowledge of the what, how, and why so that we can make practical decisions to change and improve reality for a more general good than for selfish reasons. This view is clearer in Al-Qahtani and Al-Nafisi (2017), that "critical thinking involves basic intellectual skills, but these skills can be used to serve two incompatible ends: self-centeredness and fairmindedness. To be a good critical thinker, one must strive to be fair-minded in the use of the mind in all human endeavors especially as regards interpretation of information, interaction with others and in passing judgment. It involves looking critically at the self, and the world around the self, so as to know how best to conduct the self in relation to the surrounding world. It also involves 
being receptive to information about the world, because, it is difficult if not impossible to think critically out of ignorance. This was also reinforced in Foresman et al. (2016; p.5) when they showed the nature of selfexamination in Socrates as that:

... critical thinking is about self-understanding. It is part of that ancient project enshrined in the inscription on the Greek temple at Delphi: "know thyself." With critical thinking we produce critiques not just of arguments, data sets, propositions, and texts in the abstract. We also produce critiques that reveal ourselves, especially as we are limited, weak, finite, and only human. Thinking about the world, about others, and about ourselves in light of a reflective and critical selfunderstanding of the human condition may be even more important than winning arguments or unreflectively accumulating facts, wealth, and power. It may, indeed, be the most important critical thinking outcome of all.

A close look will reveal that critical thinking is the questioning of the bases of one's own fundamental assumptions and speculations. It is an attempt to comparatively verify perspectives in order to make the best out of experience. In critical thinking, one is not just merely curious, also, one does not accept things on the surface value or settle over mere impulses regardless of how compelling they may seem. But one must question the fundamental principles that are directive of reason towards such compelling standpoint to verify if there can be better alternatives and bases to accept or discard them. Critical thinking compels us to questions not only the answers we get, but the questions and motives that bring them about. Socrates masterfully understood this when he denied having any knowledge and questioned those of others who claimed to have some sort of knowledge.

Critical thinking is "your ability to evaluate truth claims and cultural values objectively, meaningfully, and independently (Rational Inquiry, 2006). This means that, critical thinking is neither egocentric nor ethnocentric. It discourages any form of bias that can serve as a hindrance to truth. For Al-Qahtani and Al-Nafisi (2017; p.9), as critical thinkers we analyze our thinking. As humans we think egocentrically; as critical thinkers we expose the egocentric roots of our thinking to close scrutiny. As humans we live with the illusion of intellectual and emotion freedom; as critical thinkers we take explicit intellectual and emotional command of who we are, what we are, and the ends to which our lives are tending. As human thinkers we are governed by our thoughts; as critical thinkers we learn how to govern the thoughts that govern us. These clearly distinguished what it means to be a critical thinker, beyond what it means to be human. As such, it can be deduced that, having rationality is human, but being a critical thinker requires more than merely possessing a rational capacity. It involves putting it to use for the improvement of the human condition and understanding. If this is what critical thinking is, what then is philosophy? But before exploring the answer to that seemingly simple question, let us examine briefly, the notion of rational inquiry.

\section{THE NOTION OF RATIONAL INQUIRY}

Rational inquiry is the study of how people are able to give explanation of how humans can know so much when evidences are so scarce and may not even be reliable when they are available. It is how they come to have reliable knowledge about the world they live in (Rational Inquiry, 2006).

Rational inquiry is the point of intercourse between philosophy and critical thinking. The capacity to be rational, to think, to process experience in such a manner that remembers the past to relate it to the present and make inferences or conclude on future possibilities and projections, is a matter of strict rational capacity. This has also for a long time been understood as an exclusively human thing.

There is an age-old assumption that thinking distinguishes man from the beast. This we shall accept. What makes man nobler than the beast is what he possesses through thought. Whatever is human is so only to the extent that therein thought is active; no matter what its outward appearance may be, if it is human, thought makes it so. In this alone is man distinguished from the beast (Quentin Lauer, 2021).

As such, we can see that, all things being normal, thought is to human as life is to the living. But to think is not the same as to make a rational inquiry. For rational inquiry to occur, the curiosity of philosophy must come in contact with the questioning and "skepticismic" act of critical thinking. For rational inquiry to take place, there must be an object that the mind must be interested in. There must be a subject, the human person, who is interested in that object. That interest triggers curiosity in the mind of that human person. While the curiosity lasts, different explanations will present themselves, both within and without the person. The questioning of those explanations then begins to open side by side the doors of knowledge and ignorance towards the attainment of truth.

\section{PROJECTING PHILOSOPHY AND ITS BASIC ASPECTS}

After taking a look at what critical thinking is and demonstrating the idea of rational inquiry, it may suffice to project what philosophy is before they can be clearly juxtaposed to show how they differ and how they relate. Although philosophy has been clear to each philosopher within his or her own conception, it has had a difficult time 
being generally agreed upon. As such this may add to the perspectives of the conception of philosophy.

While insinuating that the absence of disagreement based on perspectives in philosophy will naturally bring an end to philosophy, Graham Priest called attention to the fact that "the nature of philosophy is itself a philosophical question, so uncontentious answers should not be expected (Priest, 2006). Similar to this, is the view of Paul Moser, who, while attempting to describe the condition of professional philosophy, is of the view that, the profession of philosophy is fractured in its portrait of philosophy including its core understanding of what philosophy is (Moser, 2016).

If we take the most common and perhaps the oldest definition of philosophy, from Greek, by way of Latin, philosophia, translated to mean love of wisdom (Philosophy, 2020), we will see and understand that it is more or less the attempt to acquire and exhibit the traits of wisdom, we will see that the love of wisdom may be wise, but the love of wisdom cannot be equated with wisdom. What then is wisdom? It may suffice to define wisdom, as "the trait of utilizing knowledge and experience with common sense and insight (Word Web dictionary, 2020). The implication of this is that, to use knowledge and experience with common sense, but without insight is not wisdom. Just as to use knowledge and experience with insight but no common sense may be impossible.

Another attempt to define philosophy holds that: philosophy is the rational, abstract, and methodical consideration of reality as a whole or of basic dimensions of human existence and experience (Philosophy, n.d.). Similar to this, is the view of Paul Tillich, who defined philosophy as "the attempt to answer the most general questions about the nature of reality and human existence (Tillich, 1957; p.9 as cited in Moser, 2016).

Aspects of philosophy include logic, metaphysics, ethics, epistemology, aesthetics, socio-political philosophy and the philosophies of other disciplines. It is noteworthy that the nature of philosophy is not different in all of its aspect, it is just the subject matter upon which they focus that differ. While metaphysics deals with the ideas of the fundamental nature of things. Logic focuses on the criteria and standards for the determination of good and bad reasoning. Ethics focuses on the nature and standards of morality. Epistemology deals with theories of, and criteria for, what can be called knowledge. Socio-political philosophy deals with the theories of state and governance. And finally, the philosophies of other disciplines deal with the theories and underlying assumptions of all others disciplines that were birthed from philosophy.

Examining these definitions of philosophy, and how plausible they are, even as they differ. It will be seen that one of the many things they may have in common, is the critical thinking DNA. As such, the act of philosophizing could only have to be carried out and fulfil its qualities through the act of critical thinking. And if that is to be true, they cannot be one and the same thing. The critical thinking DNA though is prominent in philosophy, does not make philosophy and critical thinking one and the same thing. Just as the love of wisdom may be wise, but does not make wisdom and the love for it, one and the same thing.

\section{LINKING THE DOTS: THE CRITICAL THINKING DNA}

Analogically speaking, critical thinking can be likened to the word "man." The word and reality of, man, is present in the word "woman." The idea of woman is different from the idea of man, but can pass for a context of man in meaning human. But to be human is fundamentally neutral, just as to be man can be used in a neutral and specific manner. This kind of relationship of man being in and yet remaining different from woman while they both have the fundamental human DNA, is the relationship between philosophy and critical thinking. Philosophy carries the critical thinking DNA, but is different from critical thinking.

By DNA, I am only likening the core of the fundamental characteristic genetic information of critical thinking and philosophy to that of the biochemical king of all molecules. The Deoxyribonucleic acid which is "a long linear polymer found in the nucleus of a cell and formed from nucleotides and shaped like a double helix; associated with the transmission of genetic information (Word Web dictionary, 2020) in simpler terms, DNA codes genetic information for the transmission of inherited traits (Margulis et al., 2020). But the biology or biochemistry of DNA is not the main focus of this topic. What needs to be understood is that, as there is a peculiar trait that is hereditary in living organisms, so are traits that critical thinking and philosophy have that are inherited by other disciplines or off springs of rational inquiry these traits are what are here referred to as DNA. As such, while the DNA of philosophy is curiosity, the DNA of critical thinking is skepticism.

When Socrates said as he was believed to have adopted from the inscription at Delphi "man know thyself" (Green, 2018; p. 1), there is already so much in it that conveys a deep-rooted philosophical prescription. But he further pondered and admonished that "an unexamined life is not worth living" (Green, 2018; p. 6). This prescription of examination marks the entry of critical thinking. How? You may wonder. The need for the knowledge of self, stems from curiosity. But the examination of one's life to the point of having an informed self-knowledge stems from skepticism.

Socrates is arguably the most obvious philosopher and critical thinker in the history of ancient Greek philosophy. This was because of his method of interlocution which he insisted on continuing with even to the point of death. $\mathrm{He}$ proceeded by breaking every claim to knowledge into the finest understanding. Showing the limits, the pros and cons, showing the implication of every answer and question. When he called attention to self-knowledge, he 
understood that anything can pass as the self, and anything can pass as the bases for or the knowledge of the said self. Hence the reason why he gave a definite shape to the head of the baby, by adding that an unexamined life is not worth living. From this, it can be deduced that the critical self-examination is what brings about the critical self-awareness that makes one understand himself, his place in reality, the relationship between that self and reality and how best to comprehend the whole of nature as the bases of a worthwhile existence.

A person could look at himself and say, "I am me, or I am myself." Or even say that "I know myself." But then, when you look closely, you will wonder the evidence of the traits of such self-awareness in the person. When one claims to have knowledge, you will be forced to wonder if it is about his knowledge or his own ignorance, and which of either is more worthwhile to the implications of the human person. Therefore, philosophy takes you to the door of the need for whether or not you will know yourself. But critical thinking brings you in and gives you the tour around the awareness of your infinite ignorance and develops the habit of critical skepticism in you. This critical skepticism is what makes you always stop to think and ask particular questions, not in the attempt to exhibit your own knowledge but to come to terms with your ignorance. This is the critical thinking DNA.

The critical thinking DNA can also be found in Rene Descartes who in his "methodic doubt" denied all he knew and doubted all knowledge in attempt to arrive at an indubitable fact that will serve to quench the thirst of disagreement in the philosophical traditions. He eventually arrived at the consciousness of his own act of doubting. He understood that he had to exist to be skeptical. And on the bases of that discovery, he concluded cogito, ergo sum. Meaning, I think, therefore I am, which according to Brian Duignan was later suggested to be indeed the conclusion of a syllogism whose premises include the propositions that he is thinking and that whatever thinks must exist (Duignan, n.d).

The critical thinking DNA is characterized by a careful skepticism which results into the scrutiny of all claims. Such skepticism is necessary in order to advance truth, regardless of the logical implication of evidence. This is because, sometimes, evidence can, in a compelling manner, imply something that is totally contrary to the truth. No wonder critical thinking is the most important skill of man. As it can be found at the core of man's most important efforts in the search for truth. While philosophy questions the foundations of all things, critical thinking questions the foundation of philosophy as well as itself. While the answers given to the philosophical questions about all disciplines define them away from philosophy, critical thinking proceeds with them in their further navigation to meander the interstices of assumptions and experimentation towards arriving at truth.

For examples, when science defined itself methodologically away from philosophy, it was based on the critical answers given about the way it proceeds with its inquiry. Philosophers and scientists used to be on the same page until questions of methods to arrive at, and perspectives to, truth came up. The questions about the truth of human resources and its management broke economics out of science. The question about state and the way it should be conceived and managed broke political sciences away from natural science and philosophy etc. but regardless of the time, stage, perspective and reasons for the breaking out of disciplines from philosophy and science and their subdivisions and specializations, the fact of critical thinking perseveres in and through them all. Philosophy and the philosophical DNA may determine where each and every discipline may begin. But it is the critical thinking DNA that gets them to begin, begins with them and sees them through on the journey to discover their bits and pieces of the truth about the whole of reality.

This DNA of critical thinking can be found in the fact that all disciplines start with and set out to the attempt to uncover their ignorance in peculiar cases. As such, it may suffice to say that all true knowledge may be evidence or a discovery, of one's ignorance. This was clearly understood by no less a person than Karl Popper, whose version of critical thinking in sciences he named "critical rationalism (Afisi, 2015; p.35), a view that was very influential and thoroughly sieved to remain a minimum three elements that were presented by Hans Albert in his attempt to correct the misunderstanding of the Frankfurt School against the position of Popper and his followers. $\mathrm{He}$ rightly stated that there are three core assumptions of critical rationalism that are common to critical rationalists regardless of their difference in its conception and or application. These are:

1. consistent fallibilism, the assumption that all humans are fallible, not only in their cognitive practice but also in all their attempts at problem solution.

2. critical realism, the assumption that we are able, in principle, to recognize real connections that are independent from us, that is, to arrive at true statements about these.

3. methodological revisionism, the assumption that all of our assertions may require revision following critical examination (Albert, 2015; p.210).

It is noteworthy that, the capacity to doubt, to think and to make choices are evidences that truth is necessary in all cases, to man. Every thought and assumption that precede every decision man makes, is from a perception or expectation, of some sort of truth that may or may not be the case.

As such it is safe to say that while philosophy questions everything and everyone else, critical thinking questions philosophy and itself. While a philosopher questions the world, the critical thinker questions the bases upon which the said world is questioned. While philosophy attempts answers to the general questions about reality, critical 
thinking examines questions and answers about particular realities. These are done in order to be sure that the motives are right and the efforts are free from all forms of bias and prejudices.

\section{EXCUSING THE FEMINISTS}

It is clear that the gender dichotomy has come to play in this work, based on the attribution of gender roles between philosophy and critical thinking. But those were meant in no condescending sense. But in the most fundamentally biological sense to exemplify the relationship between philosophy and critical thinking. This was not meant to present a difference in the case of which one will be inferior or superior to the other, rather, it was meant to show a relational difference of independence and complementarity. This is because, if philosophy did not exist to be fertilized by critical thinking and critical thinking did not exist to fertilize philosophy, both may not have made the best of their potentials. As such it may be safe to say that the entire world of rational inquiry owes their value and utility to the role of both philosophy and critical thinking, and not to either, alone.

\section{EVALUATION AND CONCLUSION}

While philosophy deals with theories, critical thinking accounts for practice or choices. While philosophy concerns itself about the accounts of concepts, critical thinking accounts for decisions. I.e., philosophy has been shown to deal with principles while critical thinking deals with practice in terms of action. Example, you many come to an assortment of understanding of the concept of work when philosophy interrogates the concept of work, but whether or not you should work, and the type of work you should do, philosophy will not tell you. What then will tell you, it is critical thinking.

The capacity to reason out of curiosity is what philosophy is centered on. But critical thinking involves decision making skills based on the evaluation of evidence. On the one hand, philosophy examines concepts to bring about theories. With the use of critical thinking, philosophy ponders on the theoretical nature of things to identify and classify them. But on the other hand, critical thinking examines options and facts to carry out decisions and give relevance to the activities of philosophy as well as those of other disciplines. While philosophy is passive, critical thinking is active. It is critical thinking that gives relevance to philosophy and other disciplines.

A critical look will show that, no theory can be arrived at without critical thinking, and no theory can be applied to any meaningful use, without critical thinking. As such, philosophy is sandwiched in critical thinking.

The seeming divorce between philosophy and critical thinking is the reason why philosophy in the hands of philosophers seem not to be living up to its full practical potentials because they have taken to falling in love with its theoretical discussions rather than practical applications of the rational capacity of man. As such, it is recommended that philosophy and critical thinking be reconciled alongside the whole family of rational inquiry for practical relevance and improvement of the human condition through interdisciplinarity. In this, when philosophy poses as both the mother and father of all disciplines, the absurdity of such makes it difficult to accept both her and her claim. But the rejection that both of them are one and the same thing, does not presuppose that it is needless for them to cooperate.

The term interdisciplinarity is used to mean the state or quality of being interdisciplinary. To be interdisciplinary is the state of drawing from or being characterized by participation of two or more fields of study (Word Web Dictionary 2020; Merriam Webster's dictionary and Thesaurus, 2020). Here, it is used to describe the interrelatedness of the fields of study based on the presence of the critical thinking DNA and their maternal origination from philosophy.

As such, borrowing from the view of Anaxagoras, who, in his account on the nature of reality, was of the view that there is a little bit of everything in everything else (Anaxagoras, 2020, Anaxagoras, 2019; Patzia, n.d), it can be estimated that there is a relational bit of every discipline in every other discipline. i.e. all disciplines can be seen to have some sort of relationship when they are carefully examined. But each discipline will manifest more of what it is about, according to how it is defined, through its philosophical foundations and its critical thinking DNA.

Therefore, all the entire fields of rational inquiry must be seen to have the same responsibility of improving the human condition, if not, they would have failed. As such, each and every one must as a matter of responsibility measure its level of success based on its relevance to the improvement of the human condition. Based on this, it can be said that all the fields of rational inquiry can find common grounds for reconciliation and cooperation in their origin (philosophy and critical thinking) and their ultimate end and purpose, which is the improvement of the human condition.

\section{CONFLICT OF INTERESTS}

The author declares that they have no conflict of interests.

\section{REFERENCES}

Afisi, O. T. (2015). Karl Popper's critical rationalism and the politics of liberal-communitarianism. A thesis submitted in partial fulfilment of the requirements for the Degree of Doctor of Philosophy in Philosophy in the University of Canterbury. $p$. 35.

Ajanwachukwu, O. E. (2015). Reason as the guide in human 
action: Aquinas' Ethics. IOSR Journal of Humanities and Social Science, 20(0), 61-66.

Albert, H. (2015). Karl Popper, critical rationalism, and the positivist dispute. Journal of Classical Sociology, 15(2), 209219.

Al-Qahtani, N., \& Al-Nafisi, B. (2017). Chapter 3: Becoming a fairminded thinker. Retrieved from https://slideplayer.com/slide/ 12368134/

Anaxagoras (2019). Stanford encyclopedia of philosophy. Retrieved from https://plato.stanford.edu/entries/anaxagoras/.

Anaxagoras (2020). Encyclopedia Britannica. Ultimate reference suite. Chicago.

Baggini, J., \& Fosl, P. (2010). The philosopher's toolkit: A compendium of philosophical concepts and methods, second edition, Blackwell Publishing Ltd. p. 23.

Changwong, K., Sukkamart, A., \& Sisan, B. (2018). Critical thinking skill development: Analysis of a new learning management model for Thai high schools. Journal of International Studies, 11(2), 37-48.

Diestler, S., \& Mahy, C. (1998). Becoming a critical thinker: $A$ user friendly manual (p. 512). Upper Saddle River ${ }^{\wedge}$ eNJ NJ: Prentice Hall.

Duignan, B. (n.d). Cogito, ergo sum: Philosophy. Britannica. Retrieved 12th February 2016 from https://www.britannica. com/topic/cogito-ergo-sum.

Foresman, G. A., Fosl, P. S., \& Watson, J. C. (2016). The critical thinking toolkit. John Wiley \& Sons, Chichester, UK. p. 5.

Green, M. S. (2018). Know Thyself; the value and limits of selfknowledge, Routledge, New York and London. Retrieved 2nd December 2021 from https://humilityandconviction.uconn. edu/wp-content/uploads/sites/1877/2017/11/GREENKnow ThyselfEXC.pdf.
Margulis, L., Sagan, C., \& Sagan, D. (2020). Life: Encyclopedia Britannica. Retrieved 1st December 2021 from https://www.britannica.com/science/life.

Merriam Webster's dictionary and Thesaurus (2020).

Moore, B. N., \& Parker, R. (2009). Critical thinking, 9th edition. California State University, Chico: McGraw-Hill. p. 3.

Moser, P. K. (2016). Philosophy, Christian Philosophy, and Christian Faith: Reply to Hasker. Roczniki Filozoficzne, 64(4), 41-54.

Patzia, M. (n.d). Anaxagoras (c.500-428 B.C.E.). Internet encyclopedia of philosophy. Retrieved from https://www.iep.utm.edu/anaxagor/\#H2.

Philosophy (2020). Encyclopedia Britannica. Ultimate reference suite. Chicago.

Philosophy (n.d). Retrieved from https://www.britannica.com/ topic/philosophy.

Priest, G. (2006). What is philosophy? Philosophy, 81(316), 189207.

Quentin Lauer, S. J. (2021). Hegel: Introduction to the History of Philosophy. Retrieved 1st December 2021 from https://www.marxists.org/ reference/archive/hegel/works/hp/hpintroduction.htm.

Rational Inquiry (2006). Rational Inquiry. University of HoustonDowntown. Retrieved from http://gator.uhd.edu/ hagen/ hum3310.pdf.

Salmon, M. H. (2007). Introduction to logic and critical thinking, 5th edition. Thomson Wadworth. p. 3.

Word Web dictionary (2020). 